\title{
The Absence of a Debate Strategy for the Reality of the Teaching of Islamic Science in Education High Schools in Saudi Arabia
}

\section{Introduction}

Islam is a religion that is broad and rich in subjects and areas developed since its emergence fourteen hundred years ago. The religion that began with the Qur'an and the traditions of the Prophet Muhammad as the only religious knowledge in the first generations of Muslims later required other aspects of knowledge to help understand the two core sources of the Qur'an and the Traditions of the Prophet. Therefore, with time, a number of areas of knowledge such as the science of Qur'an, the science of Hadith, Tawhid, Shari'ah, various dialects of Qur'anic recitation and other smaller areas of knowledge were all developed in order to complement the knowledge of the Qur'an and the Tradition of the Prophet. These areas of knowledge have been taught through centuries since the time of the Prophet to date. These areas of knowledge must be learned by all Muslims as they pertain to spiritual matters, the worship of Allah as the creator and sustainer of the universe, and how Muslims should conduct themselves in their relationship with Allah, their fellow human beings, as well as how to balance the life here and that in the hereafter.

In contemporary times, Islam is the second largest, as well as the fastest growing, religion in the world. What started in the town of Makkah has now spread into every corner of the earth. The need for Islamic education is as important as it has ever been because of the new generations of Muslims coming up as well as the new converts who are flooding into the religion. It is not only preservation and continuity that are needed with regard to Islamic education. In addition, with changing times as well as the socio-economic forces of the contemporary global world order, Islamic education must adapt new ways and methods of teaching that suit the context of today's reality and offer students more exciting, interactive and lively ways of learning. Doing so will make sharing the knowledge of Islam, which is considered compulsory on every Muslim and Muslimah, easier and more attractive to Muslims, as well as to non-Muslims who are curious about the religion.

One of the various ways of teaching which has recently been gaining attention from curriculum developers, scholars and teachers in Islamic knowledge is debate strategy which is a distinctive, organized, discursive and one of the strategic 
teaching methods that involves a dialogue among small group of people discussing a particular issue or topic ${ }^{1}$. Simply put, debate is a form of dialogue that helps participants, listeners or readers find answer or solution between two or more parties engage in the debate by talking about a topic and exchanging ideas to deliver their different opinions ${ }^{2}$.

Debate itself is not a totally new method in teaching. It dates all the way back to the Greek philosophers as it was shaped by the Sophists (5th century BC) who developed a dialectic rhetorical method. The great Greek philosopher, Socrates, was known for his dialectic method through which he would prove a wrong and fix a mistake, clear confusions and inform the truth ${ }^{3}$. The Qur'an also gave a number of stories in which a debate was used and urged Muslims to use the method of debate to educate and inform others about the truth. One of those instances the Qur'an mentioned was the debate between Prophet Ibrahim and a king who challenged Ibrahim about the existence of Allah. Despite being a method inherently encouraged by the Qur'an, the debate strategy method could hardly be found in the modern methods of teaching Islamic disciplines.

Therefore, the aim of this study is to reintegrate debate strategy and make it a method of teaching of Islamic education in a modern way.

\section{Problem Statement}

The teaching of Islamic subjects in schools is still dominated by the fundamental approach to formal education which is designed in a unidirectional form, from teacher to learner, and homogenous (same for all) in nature, using a standard curricular and uniform methods of teaching ${ }^{4}$. The traditional methods of teaching Islamic knowledge lack interactivity which makes Islamic knowledge monotonous to learn and the environment less exciting 5 . This problem is inherent in the system of education in countries like Saudi Arabia where the method employed in teaching Islamic studies is said to be based on the Qur'an and Sunnah method ${ }^{6}$.

\footnotetext{
${ }^{1}$ W. Ismail, M.A. Zailani, Z. Hussin, F.M. Mohamed, R. Saad, S. Kamaruzaman, A. Suliman, Effectiveness of the debate strategy in the teaching of Islamic Sciences (n.d.).

${ }^{2}$ M. Najafi, Z. Motaghi, H.B. Nasrabadi, K.N. Heshi, "Debate” learning method and its implications for the formal education system, "Educational Research and Reviews" 2016, Vol. 11, No. 6, pp. 211-218.

${ }^{3}$ Ibidem.

${ }^{4} \mathrm{M}$. Ridhuan, Development of activity-based mlearning implementation model for undergraduate English language learning. A PhD. Thesis submitted to the Faculty of Education, University of Malaya 2014.

${ }^{5}$ W. Jusoh, K. Jusoff, Using multimedia in teaching Islamic studies, "Journal of Media and Communication Studies" 2009, Vol. 1, No. 5, pp. 86-94.

${ }^{6}$ S. Al Otaibi, Study of Islamic teaching method in Saudi Arabia. A Master thesis submitted to the Graduate College of Bowling Green State University 2014, https://etd.ohiolink.edu/!etd. send_file?accession=bgsu $1395603595 \&$ disposition=inline, retrieved 6.10.2017.
} 
The reason for this lack of interactivity in the traditional methods of teaching Islamic studies is the inability of the traditional methods to cope with the contemporary demands of the modern world. Islamic civilization faces stagnation without innovating new ideas at the practical level ${ }^{7}$. This is reflected in the failure of Islamic educators to comprehensively address the challenges that lead to the linking of Muslims to "backwardness" and stagnation". Some scholars believe that the failure of Islamic studies to address such challenges is rooted in the inability of Islamic education to nurture critical thinking skills among students? .

\section{Objective of the Study}

The major objective of this study is to identify the needs of debate strategy in teaching Islamic education for schools based on students' views; the study will seek to answer the research question:

What are the students' perceptions on the use of debate strategy to teach them the subject of Tawhid?

\section{Debate in Education}

According to Doody and Condon ${ }^{10}$, debate is a process of considering multiple viewpoints and arriving at a judgment that individuals and groups alike employ in order to convince themselves or others about an opinion they hold. This definition has also been echoed by Kennedy ${ }^{11}$ who added that debate goes back over 4000 years to the time of the Egyptians.

Many other scholars are of the view that in-class debate involves a two-way approach whereby learners participate in the learning process, get the chance to express themselves, develop the higher order of thinking, bring an end to rote memorization and misunderstanding, and motivate the learners, as well as helping them to stay away from prejudice, and make informed decisions and judgments based on valid sources of data ${ }^{12}$.

${ }^{7}$ M.F. Alshaari, Z. Ismail, A. Puteh, M.A. Samsudin, M. Ismail, R. Kawangit, H. Zainal, B.M. Nasir, M.I. Ramzi, "Procedia - Social and Behavioral Sciences” 2012, Vol. 59, pp. 618-626.

${ }^{8}$ Ibidem.

${ }^{9} \mathrm{H}$. Rosnani, Rethinking Islamic Education in Facing the Challenges of the Twenty-first Century, "American Journal of Islamic Social Sciences" 2005, Vol. 22, No. 4, pp. 133-147; T. Ramadan, Western Muslims and the Future of Islam, Oxford University Press 2004.

${ }^{10} \mathrm{O}$. Doody, M. Condon, Increasing student involvement and learning through using debate as an assessment, "Nurse Education in Practice" 2012, Vol. 12, Issue 4, pp. 232-237.

${ }^{11} \mathrm{R}$. Kennedy, In-class debates: Fertile ground for active learning and the cultivation of critical thinking and oral communication skills, "International Journal of Teaching and Learning in Higher Education” 2007, Vol. 19, No. 2, pp. 183-190.

${ }^{12}$ O. Moomala, M. Faizah, F. Amiri, An English debate league competition among lower form students: An experiential learning activity, "US-China Foreign Language" 2013, Vol. 11, No. 11, 
In the relationship between debate and critical thinking, $\mathrm{Kuhn}^{13}$ believes that one of the major factors developing critical thinking ability is a social one whereby an idea is discussed with peers to collaboratively develop knowledge. Moreover, the use of debate can enhance critical thinking skills through defining the problem, assessing the credibility of sources, identifying and challenging assumptions, recognizing inconsistencies and prioritizing the relevance and salience of various points with the overall argument ${ }^{14}$. Debates raise the level of students' motivation and interests in the taught content which enables students to think critically by reasoning, evaluating, understanding, conceptualizing, and reflecting on the literature ${ }^{15}$.

In addition, Krieger ${ }^{16}$ also found that debate played a huge role in helping students to progress in their ability to express and defend ideas, as well as helping them to recognize flaws in each others' ideas and arguments, which is considered a key component of critical thinking. The development of critical thinking skills in using debate strategy in teaching and learning is one of its most salient features ${ }^{17}$. Learners are required to gather enough evidence while preparing for rebuttals in order to support their arguments and viewpoints ${ }^{18}$. A similar view has also been stated by Doody and Condon ${ }^{19}$ where they argued that debate helps learners to develop critical thinking skills by learning how to define a problem, evaluate the reliability of resources, identify and challenge assumptions, recognize contradictions, and prioritize the relevance and importance of different viewpoints in the overall course of a discussion. In addition

pp. 840-852; O. Doody, M. Condon, op. cit., pp. 232-237; C.H. Yang, E. Rusli, Using debate as a pedagogical tool in enhancing pre-service teachers' learning and critical thinking, "Journal of International Education Research" 2012, Vol. 8, No. 2, pp. 135-144; D. Rear, A systematic approach to teaching critical thinking through debate, ELTWorldOnline.com, 2010, Vol. 2, pp. 1-10; R. Kennedy, op. cit., pp. 183-190; M. Darby, Debate: A teaching-learning strategy for developing competence in communication and critical thinking, "Journal of Dental Hygiene" 2007, Vol. 81, Issue 4, pp. 1-10; N. Tumposky, The debate debate, "Clearing House" 2004, Vol. 78, Issue 2, pp. 52-55, http://dx.doi.org/10.3200/TCHS.78.2.52-56, retrieved 6.10.2017.

${ }^{13}$ J. Guiller, A. Durndell, A. Ross, Peer interaction and critical thinking: Face-to-face or online discussion?, "Learning and Instruction" 2008, Vol. 18, Issue 2, pp. 187-200.

${ }^{14} \mathrm{R}$. Kennedy, op. cit., pp. 183-190.

${ }^{15} \mathrm{M}$. Munakata, The mathematics education debates: Preparing students to become professionally active mathematics teachers, "Primus" 2010, Vol. 20, Issue 8, pp. 712-720, http://dx.doi.org/10. 1080/10511970902870372, retrieved 6.10.2017; J. Guiller, A. Durndell, A. Ross, op. cit., pp. 187-200.

${ }^{16}$ D. Krieger, Teaching debate to ESL students: A six-class unit, "The Internet TESL Journal" 2005, Vol. 11, No. 2, http://iteslj.org/Techniques/Krieger-Debate.html, retrieved 28.08.2013.

${ }^{17} \mathrm{~S}$. Scott, Perceptions of students' learning critical thinking through debate in a technology classroom: A case study, "The Journal of Technology Studies" 2008, Vol. 34, No. 1, pp. 39-44.

${ }^{18}$ C.H. Yang, E. Rusli, op. cit., pp. 135-144; M. Munakata, op. cit., pp. 712-720; M.Y. Omelicheva, Resolved: Academic Debate Should Be a Part of Political Science Curricula, "Journal of Political Science Education" 2007, Vol. 3, Issue 2, pp. 161-175, http://dx.doi.org/10.1080/15512160701338320, retrieved 6.10.2017.

${ }^{19}$ O. Doody, M. Condon, op. cit., pp. 232-237. 
to teaching students critical thinking skills, using a qualitative descriptive approach $^{20}$, debate was also found to have various instructional and educational functions which include mastery learning, creating a learning continuum, continuity in the learning, thinking centered learning, creative thinking, increasing the speed of learning, promoting the evaluation power, promotion of entrepreneurial skills, promotion of mental health, developing verbal skills, teaching critical thinking and promoting social skills.

The use of debate in teaching requires that learners engage in constructive teamwork to unify their position and eliminate redundancy which allows the learners to take on a position and express their opinions/argument while ensuring the maintenance of composure during analytical rebuttals ${ }^{21}$. This makes debate an excellent tool for dealing with controversial courses and disciplines of education. In addition, according to Walker and Warhurst ${ }^{22}$, the use of debate also requires teachers and lecturers to step back from delivering taught content and give students the space to teach and educate one another.

\section{Debate Strategy in Islam}

Debate can be defined in the Islamic context as a dialogue between two parties on a subject, each party intending to prove his point of view and to nullify the view of the opponent, with the sincere intention revealing the truth and recognizing it once it is revealed. Debate has been a strategy that has a long history within Islamic traditions. There have been various instances of the use of debate in the holy Qur'an and Prophet Muhammad has been reported to have employed this strategy in a number of instances during the course of His prophetic life. According to Al Arify (n.d.) quoted from one of the outstanding Islamic scholars of this generation, there are a number of conditions of debate in Islam. These include:

1. Avoid talking too much so as to shorten the dialogue in order to discern the purpose of the debate.

2. Avoid using strange words and sweeping generalizations.

3. Stick to what is relevant to the topic of the debate without getting out of it.

4. Avoid mocking and making fun of each other.

5. Aim to reveal the truth even if it comes from the opponent's side.

6. Do not argue against the opponent's point until one understands what the opponent means to say.

${ }^{20}$ M. Najafi, Z. Motaghi, H.B. Nasrabadi, K.N. Heshi, op. cit., pp. 211-218.

${ }^{21}$ M. Darby, op. cit., pp. 1-10.

${ }^{22} \mathrm{M}$. Walker, C. Warhurst, In most cases you sit around very quietly at a table and get lectured at...: debates, assessment and student learning, "Teaching in Higher Education" 2000, Vol. 5, Issue 1, pp. 33-49. 
7. Wait for the opponent to complete their statement and avoid interruption while the opponent is talking.

8. Avoid looking down and demeaning the opponent which may lead to avoiding the acceptance of the truth from the opponent.

Debate and dialogue are two concepts that have been used interchangeably in the context of Islam. Literally, dialogue means exchange of statement. Its figurative meaning, however, refers to an exchange of conversation between two parties on a specific topic in which each one of the two has a different viewpoint for the purpose of arriving at the truth even if it comes from the opponent. The glorious Qur'an has mentioned this three times:

1. In Surah Al Kahf (Verse 34): "And he had property (or fruit) and he said to his companion, in the course of mutual talk: I am more than you in wealth and stronger in respect of men".

2. In Surah Al Kahf (Verse 37): "His companion said to him, during the talk with him: "Do you disbelieve in Him who created you out of dust (i.e. your father Adam), then out of 'Nutfah' (mixed drops of male semen and female discharge), then fashioned you into a man?"

3. In Surah Al Mujadalah (Verse 1): "Indeed Allah has heard the statement of her (Khaula bin Tha'laba) that disputes with you (O Muhammad) concerning her husband (Aus bin As-Samit), and complains to Allah. And Allah hears the argument between you both. Verily, Allah is All-Hearer, All-Seer".

One can argue that Muslims are obliged to engage in dialogue as a way to arrive at the truth and what is right. For example, in the glorious Qur'an the Prophet was commanded in Surah Ali Imran (Verse 64):

Say (O Muhammad): "O people of the Scripture (Jews and Christians): come to a word that is just between us and you, that we worship none but Allah, and that we associate no partners with Him, and that none of us shall take others as lords besides Allah". Then, if they turn away, say: "Bear witness that we are Muslims".

This verse is a clear indication of Islam's command of meaningful dialogue.

According to Al Sanaidy (1430/2008), there are five key features of a dialogue:

1. A deep belief and trust in what one engages in a dialogue for,

2. Knowledge,

3. Wisdom,

4. Freedom of thought,

5. Intellectual courage. 
As stated above, the concepts of debate and dialogue have been used interchangeably in the Islamic literature. While the mention of dialogue has been very clear in the holy Qur'an, the same cannot be said about the concept of debate, although many have argued that the word argue, mentioned 29 times in the Glorious Book, sometimes referred to debate. For example, in Surah Al Nahl (Verse 125):

Invite (mankind, O Muhammad) to the Way of Your Lord (i.e. Islam) with wisdom (i.e. with the Divine Inspiration and the Qur'an) and fair preaching, and argue with them in a way that is better. Truly, Your Lord knows best who has gone astray from His Path, and He is the Best Aware of those who are guided.

Though they do not use the word debate, this verse and many others imply from their contextual meanings that they intend to refer to debate rather than to an informal argument. Not only that, the context in which it is used in the verse above implies that Muslims are obliged to engage in a meaningful debate in an attempt to establish the truth and show the right path.

\section{Method of the Study}

The aim of this study to identify the students' perceptions on the use of debate strategy to teach them the subject of Tawhid, the sample of this phase involves 200 students from the Saudi School in Malaysia who are currently students at any level of the three years of secondary education.

To achieve the specific objectives of this study, a needs analysis survey questionnaire will be employed. The questionnaire consists of 12 questions revolving around the students' perceptions of Current Method of Teaching Tawhid Subject and intention to use debate strategy.

Cronbach's alpha, in this study, was used to assess the internal consistency reliability of development of debate strategy implementation model for teaching tawhid in secondary school. Shown in Table 1.

Table 1. Reliability Test of Needs Analysis Questionnaire

\begin{tabular}{|c|c|c|}
\hline \multicolumn{1}{|c|}{ Construct } & Number of Items & Cronbach Alpha \\
\hline $\begin{array}{l}\text { Development of debate strategy } \\
\text { implementation model }\end{array}$ & 20 & .852 \\
\hline
\end{tabular}

Source: Author's own elaboration. 


\section{Findings}

After ascertaining the reliability and validity of the research instrument through the pilot test, the researcher went further to conduct the real test and came up with the needs analysis for this study, Here, a total of 200 students were sampled from three different public secondary schools in the Kingdom of Saudi Arabia. The researcher distributed the survey questionnaire personally to the students in their schools and made an explanation where necessary. The effort was made to collect the survey questionnaire back after completion. Data were key-in and the result is shown in the next paragraph.

In this section, the researcher made efforts to present the result of the findings on students' opinion on the current methods of teaching Tawhid subjects in secondary schools in the Kingdom of Saudi Arabia. There are eight-items questions in this section. The result of the respondents on each of these questions is presented below:

Table 2. Students' Perception on of Current Method of Teaching Tawhid Subject and Intention to Use Debate Strategy

\begin{tabular}{|l|l|c|c|c|c|c|c|}
\hline SN & \multicolumn{1}{|c|}{ ITEM } & SD & D & N & A & SA & Total \\
\hline 1 & $\begin{array}{l}\text { The teacher does } \\
\text { most of the talking } \\
\text { while students } \\
\text { only listen }\end{array}$ & 14 & 20 & 11 & 86 & 69 & 200 \\
\hline 2 & $\begin{array}{l}\text { The current } \\
\text { method of teaching } \\
\text { Tawhid is } \\
\text { teacher-centred }\end{array}$ & 13 & 25 & 7 & 73 & 82 & 200 \\
\hline 3 & $\begin{array}{l}\text { I will be eager to } \\
\text { learn Tawhid if } \\
\text { a better method } \\
\text { is introduced }\end{array}$ & 20 & 24 & 11 & 70 & 75 & 200 \\
\hline 4 & $\begin{array}{l}\text { Using in-class } \\
\text { debate will make me } \\
\text { more active in the } \\
\text { class }\end{array}$ & 32 & 25 & 8 & 75 & 60 & 200 \\
\hline 5 & $\begin{array}{l}\text { Using in-class } \\
\text { debate will make me } \\
\text { think critically }\end{array}$ & 40 & 22 & 10 & 68 & 57 & 200 \\
\hline 6 & $\begin{array}{l}\text { Using in-class debate } \\
\text { will help me improve } \\
\text { my communication } \\
\text { skills }\end{array}$ & 39 & 25 & 12 & 63 & 61 & 200 \\
\hline
\end{tabular}




\begin{tabular}{|c|l|c|c|c|c|c|c|}
\hline SN & \multicolumn{1}{|c|}{ ITEM } & SD & D & N & A & SA & Total \\
\hline 7 & $\begin{array}{l}\text { Using in-class debate } \\
\text { will teach me how to } \\
\text { work in a team }\end{array}$ & 28 & 23 & 10 & 73 & 66 & 200 \\
\hline 8 & $\begin{array}{l}\text { Using in-class debate } \\
\text { will help me learn } \\
\text { difficult sides } \\
\text { of argument }\end{array}$ & 33 & 28 & 17 & 59 & 63 & 200 \\
\hline 10 & $\begin{array}{l}\text { Using the in-class } \\
\text { debate method } \\
\text { allows me to express } \\
\text { my view about some } \\
\text { topics in Tawhid }\end{array}$ & 20 & 24 & 8 & 68 & 80 & 200 \\
\hline 11 & $\begin{array}{l}\text { My involvement } \\
\text { in the in-class debate } \\
\text { will be exciting }\end{array}$ & 30 & 26 & 12 & 60 & 72 & 200 \\
\hline $\begin{array}{l}\text { It will be easy for me } \\
\text { to participate and } \\
\text { express myself in the } \\
\text { in-class debate }\end{array}$ & 28 & 22 & 15 & 78 & 57 & 200 \\
\hline $\begin{array}{l}\text { Iwould find in-class } \\
\text { debate easy } \\
\text { to participate }\end{array}$ & 27 & 14 & 75 & 200 \\
\hline
\end{tabular}

Source: Author's own elaboration.

Table 2 above shows the opinion of respondents on the current method of teaching Tawhid subjects in secondary schools in the Kingdom of Saudi Arabia. Based on the result above, On question number 1 in the survey questionnaire, it was found that $86(43 \%)$ of the respondents agree that their teachers do all the talking when they are teaching the subject of Tawhid while students only listen. $69(34.5 \%)$ of the respondents strongly agree that their teachers do the talking while students only listen in the Tawhid class. This shows that most of the students see the teaching of the Tawhid subject as the responsibility of their teachers because these teachers do all the talking while their students listen. Therefore, there is a need for a better and alternative method that will involve the students in the classroom teaching, not just a passive listener.

Moreover, it was found from question 2 of the survey questionnaire that $73(36.5 \%)$ of the respondents agreed that the current method of teaching Tawhid subject in secondary schools in the Kingdom of Saudi Arabia is teachercentred while the remaining $82(41 \%)$ of the respondents strongly agree that the current method of teaching Tawhid subject is teacher-centred. Since the 
majority of the respondents are in support, the researcher, therefore, concludes that the current method of teaching Tawhid subject in secondary schools in the Kingdom of Saudi Arabia is teacher-centred. This may be responsible for the reason why these students are not interested in the Tawhid class as reported above. The in-class debate method may be introduced in order to encourage active participation of students in the teaching activities in secondary schools in the Kingdom.

Furthermore, from question 3 it was found that 70 (35\%) of the respondents strongly disagree that the current method of teaching Tawhid subject does not make the subject interesting. Also, 74 (37\%) of the respondents disagree with this question claiming that the current method of teaching Tawhid subject in secondary schools in the Kingdom of Saudi Arabia does not make the subject interesting. Therefore, there is a need for an alternative method which can be provided by the in-class debate method.

As for the students' perception of the effectiveness of using debate strategy, it was found from question 4 that 75 (37.5\%) of the respondents agreed that using the in-class debate strategy for teaching Tawhid subject will make them more active while the remaining $60(30 \%)$ of the respondents strongly agreed that the use of in-class debate strategy for teaching Tawhid subject will help in making them more active. Also it was found from question 5 that 68 (34\%) of the respondents agreed that using the in-class debate strategy for teaching Tawhid in secondary school will make them think critically while the remaining $57(28.5 \%)$ of the respondents strongly agree that using the in-class debate strategy for teaching Tawhid subject will have this result.

Furthermore, $63(31.5 \%)$ of the respondents agreed that by using the in-class debate strategy for teaching Tawhid subject on question 6 and 61 (30.5\%) of the respondents strongly agree that using the in-class debate strategy for teaching Tawhid subject in secondary school will help to improve their communication skills.

The next question centres on the importance of the in-class debate strategy for enhancing teamwork among students. On this question, Table 2 above shows that $73(36.5 \%)$ of the respondents agreed that using the in-class debate strategy for teaching Tawhid subjects in secondary schools will teach them how to work as a team while the remaining $66(33 \%)$ of the respondents strongly agree with the question.

In addition, the question in item no 8 in this section relates to the importance of the in-class debate strategy in helping students to learn different sides of the argument. On this question, Table 2 shows that 59 (29.5\%) of the respondents agreed that using the in-class debate strategy in teaching Tawhid will help them to learn different sides of the argument. 63 (31.5\%) of the respondents strongly agree with this question. It can be deduced from this result that $45(22.5 \%)$ of the respondents do not support this question. This, therefore, means that whenever 
the in-class debate strategy is implored in teaching Tawhid subjects in secondary schools it will help students to learn different sides of the argument.

Considering the question in item number 9 of the survey questionnaire, it was found that $68(34 \%)$ of the respondents agreed that the use of in-class debate will allow them to express their views about some topics in Tawhid. Still, on this, $80(40 \%)$ of the respondents strongly agree that the use of in-class debate will allow them to express their views about some topics in Tawhid.

As shown in question in item number 10 that $60(30 \%)$ of the respondents agree that their involvement in the in-class debate will be exciting and $72(36 \%)$ of the respondents strongly agree that their involvement in the in-class debate will be exciting. Therefore, the researcher went further to ascertain the percentage of respondents that support or oppose this question.

Commenting on the respondents' view on question $11,78(39 \%)$ of the respondents agree that it will be easy for them to participate and express themselves in the in-class debate and the remaining 57 (28.5\%) of the respondents strongly agree that it will be easy for them to participate and express themselves in the in-class debate. It can, therefore, be concluded that a larger percentage of the respondents argued that it will be easy for them to participate and express themselves in the in-class debate.

As seen in question 12 it was found that $75(37.5 \%)$ of the respondents agree that they will find the in-class debate easy to participate in while the remaining $59(29.5 \%)$ of the respondents strongly agree that they will find the in-class debate easy to participate in.

\section{Discussion of Findings}

The researcher finds that these results are consistent with the existing literature (for example, see: Berdine ${ }^{23}$; Bonwell \& Eison ${ }^{24}$; Darby ${ }^{25}$; Elliot $^{26}$; Alén, Domínguez \& Carlos $^{27}$; Ramlan et al. $^{28}$ ). These previous studies stressed that debate strategy engages students in active learning rather than being passive learners in their classes. Furthermore, the vast majority of the students also

${ }^{23} \mathrm{R}$. Berdine, Increasing student involvement in the learning process through debate on controversial topics, "Journal of Marketing Education" 1987, Vol. 9, Issue 3, pp. 6-8.

${ }^{24}$ C. Bonwell, J. Eison, Active learning: Creating excitement in the classroom, Washington, D.C. 1991.

${ }^{25}$ M. Darby, op. cit., pp. 1-10.

${ }^{26} \mathrm{~L}$. Elliot, Using debates to teach the psychology of women, "Teaching of Psychology" 1993, Vol. 20, Issue 1, pp. 35-38.

${ }^{27}$ E. Alén, T. Domínguez, P. de Carlos, University students' perceptions of the use of academic debates as a teaching methodology, "Journal of Hospitality, Leisure, Sport \& Tourism Education" 2015, Vol. 16, pp. 15-21.

${ }^{28}$ F.A. Ramlan, N.M. Kassim, S. Pakirisamy, V. Selvakumar, The impact of debates as a teaching strategy in the classroom to medical students, "E-Academia Journal UiTMT" 2016, https://www. journale-academiauitmt.edu.my, retrieved 7.09.2017. 
believed that in-class debate strategy will galvanize their thinking abilities and stimulate critical thinking abilities in them. This is also consistent with the previous literature as has been found by studies such as Dundes ${ }^{29}$; Stenger \& Garfinkel ${ }^{30}$; Dickson ${ }^{31}$; Proulx ${ }^{32}$; Krieger ${ }^{33}$; Darby ${ }^{34}$; Doody \& Condon $^{35}$; Alén, Domínguez \& Carlos $^{36}$; Zare \& Othman ${ }^{37}$. All these studies argued that debate strategy fosters critical thinking skills in students.

Another reason that prompted the students to accept debate strategy is their belief that debate can improve their communication skills. This corresponds with the findings of various studies in the previous literature. For example, Darby ${ }^{38}$; Lin and Crawford ${ }^{39}$; Nuraeni ${ }^{40}$; and Zare and Othman ${ }^{41}$ all found in their respective studies that debate strategy of teaching leads to students' improvement of communication skills. Furthermore, another finding is that the debate strategy of teaching improves teamwork and collaborative learning. This corresponds with the findings of Kennedy ${ }^{42}$; Darby ${ }^{43}$; and Zare and Othman ${ }^{44}$ who all found in their respective studies that using debate strategy in teaching inculcate teamwork and collaborative learning among the students.

${ }^{29}$ L. Dundes, Small group debates: Fostering critical thinking in oral presentation with maximal class involvement, "Teaching Sociology" 2001, Vol. 29, No. 2, pp. 237-243.

${ }^{30} \mathrm{C}$. Stenger, B. Garfinkel, How the constructivist approach to learning can be used to attain academic standards 2003, https:/gse.gmu.edu/assets/docs/lmtip/vol2/C.Stenger_B.Garfinkel.pdf, retrieved 29.05.2017.

${ }^{31}$ R. Dickson, Developing "Real-World Intelligence": Teaching argumentative writing through debate, "The English Journal” 2004, Vol. 94, No. 1, Re-forming Writing Instruction, pp. 34-40.

${ }^{32} \mathrm{G}$. Proulx, Integrating scientific method \& critical thinking in classroom debates on environmental issues, "The American Biology Teacher" 2004, Vol. 66, No. 1, pp. 26-33.

${ }^{33} \mathrm{D}$. Krieger, Teaching debate to ESL students: A six-class unit, "The Internet TESL Journal” 2005, Vol. 11, No. 2, http://iteslj.org/Techniques/Krieger-Debate.html, retrieved 28.08.2013.

${ }^{34}$ M. Darby, op. cit., pp. 1-10.

${ }^{35}$ O. Doody, M. Condon, op. cit., pp. 232-237.

${ }^{36}$ E. Alén, T. Domínguez, P. de Carlos, op. cit., pp. 15-21.

${ }^{37} \mathrm{P}$. Zare, M. Othman, Students' perceptions toward using classroom debate to develop critical thinking and oral communication ability, "Asian Social Science” 2015, Vol. 11, No. 9, pp. 158-170.

${ }^{38}$ M. Darby, op. cit., pp. 1-10.

${ }^{39}$ S. Lin, S.Y. Crawford, An Online Debate Series for First-Year Pharmacy Students, "American Journal of Pharmaceutical Education” 2007, Vol. 71, Issue 1, https://pdfs.semanticscholar.org/ e62c/6ea0cb31d63996ee088cc8946121e88f0846.pdf?_ga=2.164229759.1739881108.16002478401132038232.1600247840, retrieved 15.09.2017.

${ }^{40}$ S. Nuraeni, The Effectiveness of Classroom Debate to Improve Students Speaking Skill (A Quasi-Experimental Study at the Eleventh-Year Students of SMAN 3 South Tangerang), A Degree Dissertation submitted to the Syarif Hidayatullah State Islamic University, Jakarta 2014, http:// docplayer.net/57618642-The-effectiveness-of-classroom-debate-to-improve-students-speakingskill.html, retrieved 29.08.2017.

${ }^{41}$ P. Zare, M. Othman, op. cit., pp. 158-170.

${ }^{42} \mathrm{R}$. Kennedy, op. cit., 183-190.

${ }^{43}$ M. Darby, op. cit., pp. 1-10.

${ }^{44}$ P. Zare, M. Othman, op. cit., pp. 158-170. 
Debate strategy is also accepted by the students, because it is linked with giving them a chance to learn many sides of the same argument. This is also supported by previous studies, as Krieger ${ }^{45}$ and Darby ${ }^{46}$ found that debate strategy enables students to be informed about different sides of the same issue. This view is also shared by other studies (see: Yang $\&$ Rusli $^{47}$; Munakata ${ }^{48}$ ).

All the findings so far discussed in this chapter show that there is need to introduce the in-class debate strategy implementation model for teaching Tawhid subject in Saudi secondary schools. This is very necessary, as argued by Venkatesh, et al. who stated that the learners should accept and intend to use a proposed solution before the implementation of the solution. Thus, the study focused on the development of debate strategy implementation model for teaching Tawhid subject in Saudi secondary schools.

\footnotetext{
${ }^{45} \mathrm{D}$. Krieger, op. cit.

${ }^{46}$ M. Darby, op. cit., pp. 1-10.

${ }^{47}$ C.H. Yang, E. Rusli, op. cit., pp. 135-144.

${ }^{48}$ M. Munakata, op. cit., pp. $712-720$.
} 